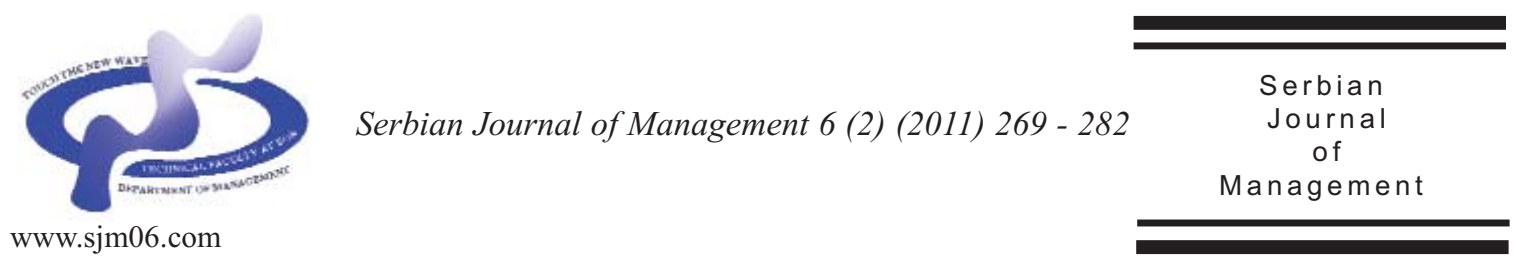

\title{
APPLICATIVE MODEL FOR APPRAISAL OF INVESTMENT PROJECTS BASED ON REAL OPTIONS METHODOLOGY
}

\author{
Dragan Lončar* \\ Faculty of Economics, University of Belgrade, Kamenička 6, 11000 Belgrade
}

(Received 17 June 2011; accepted 28 August 2011)

\begin{abstract}
This paper deals with the application of real options methodology on valuation of investment projects. The basic objective of the paper is to present applicative project valuation model, which enables decision-makers to build-up conventional NPV analysis by incorporating key input random variables, by using Monte Carlo simulation, and managerial flexibilities, by defining if-then decision rules. In contrast to most of valuation procedures covered in the literature, presented applicative model accepts simple premise that the project value is unknown in advance. Project value is not displayed with a single NPV number, but with the cumulative probability distribution. Final managerial decision does not depend on fixed decision rules, but on managerial aversion towards risk, i.e. on subjective trade-off between project risks and returns.
\end{abstract}

Keywords: investment project, valuation, real option

\section{INTRODUCTION}

Investments, which an enterprise underatakes today in form of projects, represents basic determinant of its future performances. Critical step, in the process of optimum investment selection, is valuation of investment proposals or projects. Valuation procedure is generally divided into three crucial phases. The first phase is cash flow projection for the chosen economic horizon. Second phase assumes the selection of a proper valuation methodology and the calculation of the investment indicators. Third step deals with the 'go-no go' decisionmaking based on available values of investment indicators and criteria.

This paper has two basic aims. The first aim is to provide arguments in favour of conceptual superiority of real option valuation method in the field of investment project valuation in comparison to currently dominant net present value method. The second aim is to present an applicative model

\footnotetext{
* Corresponding author: loncar@ekof.bg.ac.rs
}

DOI: $10.5937 /$ sjm 1102269L 
for investment project valuation based on real option methodology. The idea is to refocus the attention of academic and business society from complex mathematical valuation models towards applicative models based on available software solutions.

The paper is divided into four parts. First part deals with the flawed assumptions of conventional DCF analysis and the need to incorporate the value of managerial flexibility, i.e. real option, in the project value. Second part presents applicative real option valuation model supported by the advanced Microsoft Excel software. Third section displays illustrative example pertaining to description of a financial model in a single pharmaceutical company. The last part summarizes crucial results and gives concluding remarks.

\section{REAL OPTIONS WITHIN INVESTMENT PROJECTS}

Net present value (NPV) is currently dominant method for project valuation. According to a recent research study, 98\% of American companies from Fortune 500 list use this method for valuation of their projects (Andersen, 2004). Traditional NPV represents an adequate and simple tool for getting the first impression on project cash flow generation and its structure.

However, NPV has at least three serious conceptual and applicative weaknesses. First, NPV aggregates all possible project value scenarios into one, and only one, expected value scenario. Second, the function of average values of input variables usually do not give the average value of the function, i.e. the average project value. This phenomenon in literature is known as 'flaw of averages' (Savage, 2002). Third significant flaw of NPV is negligence of the value of managerial flexibility. NPV assumes one of the two things: either the investment is reversible, which means that we can restore invested money if project goes wrong, or irreversible, which means that the decision is 'now-or-never' (Dixit i Pyndick, 1995). The fact that managers can constantly change the project course, depending on the realized values of crucial input variables, is completely neglected.

The term managerial flexibility deserves more detailed elaboration. As opposed to financial assets, projects are not passive investments, because managers have possibility to make decisions during the project implementation and increase the project value. For example, instead of investing lump sum in the oil exploration project, managers may choose to invest stepby-step depending on research results. Each additional phase provides additional information, based on which the subsequent investment decision is made. On each gate, management may decide to abandon the project, to license the research right to the other company, to continue as it was initially planned, to wait with additional investments until some important uncertainties are resolved, or to fully exploit encouraging information signals, e.g. related to appropriate geological structure or increasing crude oil price, through accelerated investment activities.

Real option is a term equal to managerial flexibility at the project level. It is a discreet right of a manager to condition future project decision upon additional information about important project uncertainties (Copeland and Antikarov, 2000). The exercise of managerial flexibilities may increase the value of the project. Therefore, the value of the project may be seen as a sum of a conventional project value (i.e. passive 
NPV) and option premium that arises as a result of active project management during the project life-cycle.

Real option valuation (ROV) metholodology strives to improve DCF methodology by introducing assumption that the exercise of managerial flexibilities increases the value of the project beyond its passive value. Managerial flexibility has the highest value within unpredictable and oneoff investment projects, which NPV is close to zero, when managers, upon receive of new information, may change project course (Copeland and Antikarov, 2000: 15). In extreme cases of substantially positive or negative passive NPV, valuation of managerial flexibility usually has no sense as the valuation result does not influence the investment decision.

The difference in project risk management perspective is reflected on transition from strategy of diversifying project risks towards the strategy of active management of project risks (Figure 1). The diversification strategy is legitimate within companies that have a large number of small projects with mixed duration. However, within large investment projects, diversification of technical and commercial risks is usually not possible. What is needed

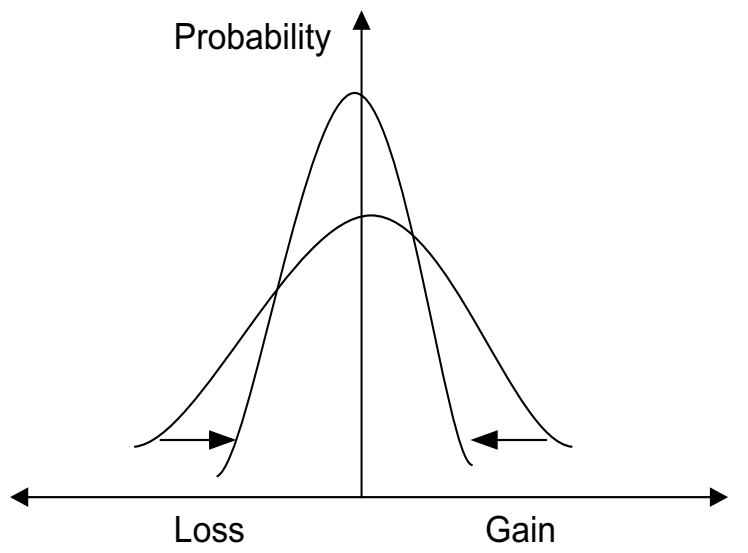

is a strategy of active project risk management, which insists on diminishing probability of large losses and increasing the probability of large gains, at the same time. This trend is visually manifested through shifting the probability distribution of project value from left to the right. Probability of large losses may be reduced through the exercise of put-like options, with the risk insurance status. For example, the company may give up investment in the subsequent phase of research and development project due to poor research results or excessive outlays in the previous phase. By abandoning the project at the right moment, the company avoids potentially extreme losses. Probability of huge gains may be increased through exercise of call-like options, which give managers possibility of multiplied valorisation of the observed opportunities. For example, by buying the flexible production facilities, the company buys the option to adjust production level according to the observed market demand. That way, in the case of steep rise in demand for a particular product, the company may absorb the demand growth to the maximum, through prompt adjustment of the production level.

Until now, we tried to stress the fact that

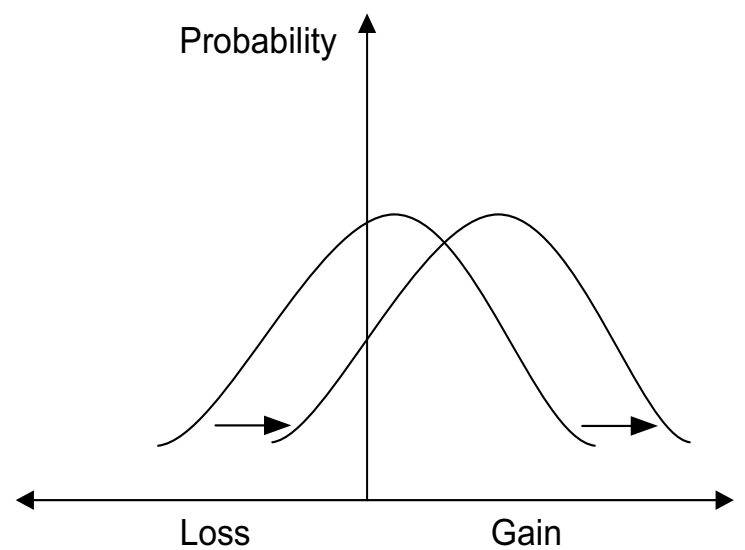

Figure 1. Diversification strategy versus Strategy of active project risk management 
managerial flexibility, if conceptualized and realized in a proper way, has value. Now, we are going a step forward with the idea to determine the value of managerial flexibility, by using the concrete applicative valuation model.

\section{APPLICATIVE REAL OPTION VALUATION MODEL}

Real options paradigm implies that the analysis of managerial flexibility must be taken into account in project conceptualisation, valuation, and implementation. This paradigm stimulates managers to adopt active risk management and adapt projects depending on the realized future scenarios.

Due to excessive complexity of theoretical real option valuation models and their meagre acceptance among business practitioners, applicative valuation models get more and more attention. Applicative ROV models are based on basic premises of theoretical ROV models, but insist on reliance on user-friendly software packages that should lead practitioners and finance managers through step-by-step valuation process and secure thorough understanding of the valuation results. For that purpose, the concrete applicative model will be presented. In short, the applicative ROV model passes through three basic steps. First step assumes understanding the nature of the project, static projection of project cash flows, and calculation of conventional or passive NPV of the project. In the second step static input variables are transformed into random variables, with the support of Monte Carlo simulation, and the project value is displayed as a probability distribution. In the third step, managerial flexibilities are incorporated in the model with if-then decision rules, and new probability distribution is derived. Final 'go-no go' decision is based on managers' interpretation of the improved probability distribution. These steps will be scrutinized below.

\subsection{Calculation of conventional NPV}

Project valuation should start with the logical cash generation model which depicts projected inflows and outflows of the project during its economic life. NPV can simply be calculated in Excel spreadsheets by summing discounted cash flows. In order to set up a good model, it is necessary to pay particular attention to projected cash flows, which are derived from projected values of input variables, such as demand, price and costs. At this point, there is a strong link between market research methodology and project valuation methodology. Wrong projections of market variables impact cash flow projections and lead to imprecise value of investment criterion. This phenomenon is described as garbage-in-garbage-out problem.

\subsection{Fluctuation of input random variables}

Instead of a single NPV number, the aim is to get the whole range of possible values of uncertain inputs and their probabilities of occurrence. This way it is possible to derive the probability distribution for the project value depending on multiple, simultaneously incorporated sources of uncertainty (how NPV changes when all inputs change at the same time). The tool that helps us do this in methodologically correct way is Monte Carlo Simulation (Figure 2). For the sake of simplicity and logically consistent 
modelling, the aim should be to identify key NPV is changed when a single random sources of uncertainty with the most palpable variable varies under ceteris paribus impact on the project value. assumption. The largest flaw of such

MCS represents significant improvement approach is incorporation of uncertainties in compared to traditional sensitivity analysis. the valuation model one-by-one, but not Traditional sensitivity analysis shows how simultaneously. Therefore, it is important to

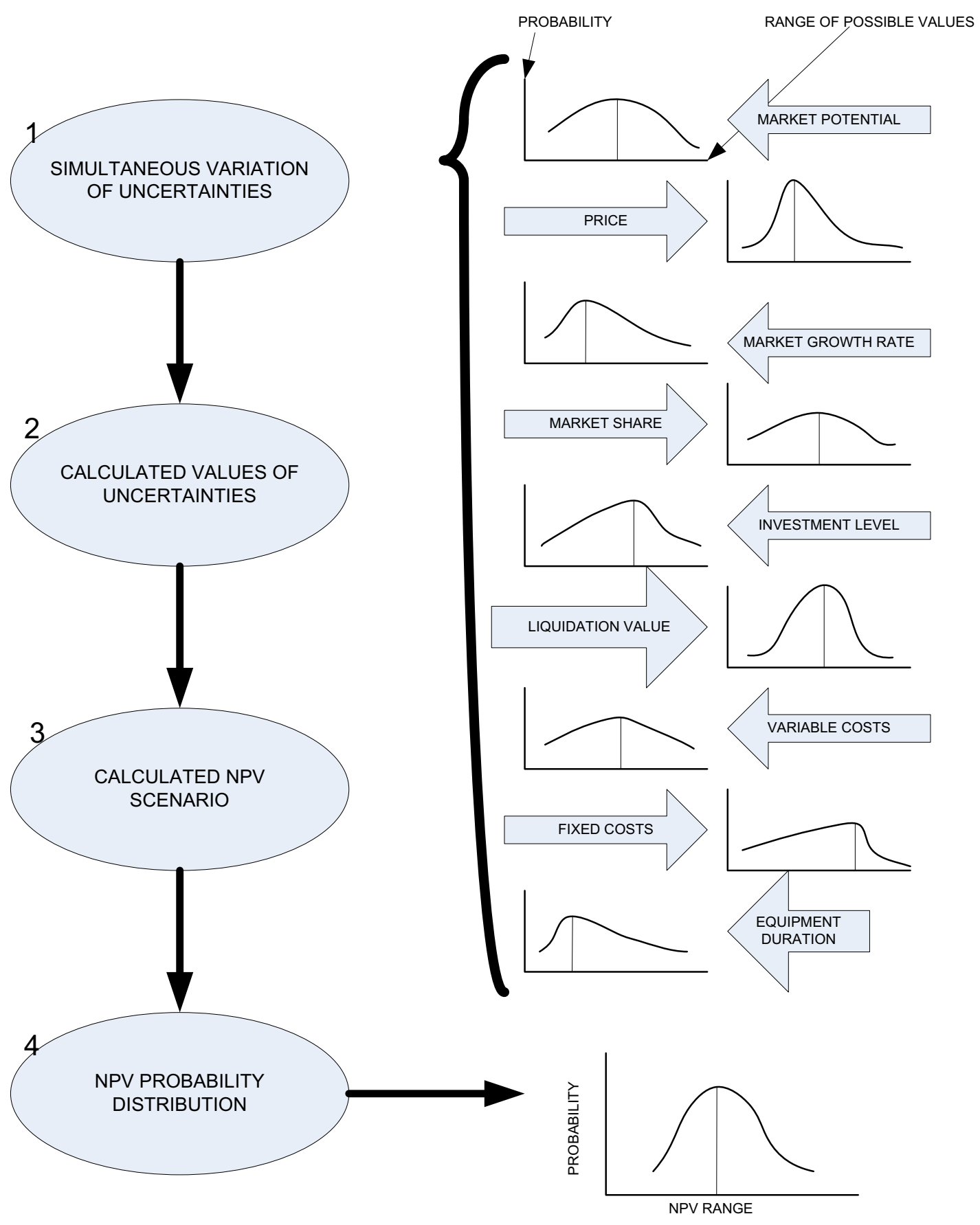

Figure 2. The logic of Monte Carlo simulation (MCS) ${ }^{1}$

\footnotetext{
1 The idea for illustration is based on fundamental MCS article: Hertz, D. B. (1964), p. 95-106.
} 
improve traditional sensitivity analysis by adding concurrent changes of all input random variables into valuation process. This approach gives much precise risk-return profile of a project, which is now a function of all the relevant input variables.

In order to incorporate input variables simultaneously, it is important to accept the premise that project value is known only ex post, after all input variables, that affect the project value, are unfolded. Currently, project value is not a single number, but the whole range of numbers with different probabilities of occurence. Probability distribution, although based on fairly complicated mathematical and statistical premises, can be easily visualized and interpreted. Range of project values and its probabilities may be simply visualized with histogram chart (Figure 3) or cumulative probability distribution (Figure 4). Cumulative probability distribution is also called value-at-risk chart (VAR chart). VAR chart is more informative than histrogram. It shows the probability that the project would earn at least $\mathrm{a} €$ or lose at the least $\mathrm{b} €$.

Now we will go one step backward and try to solve the problem related to simulation

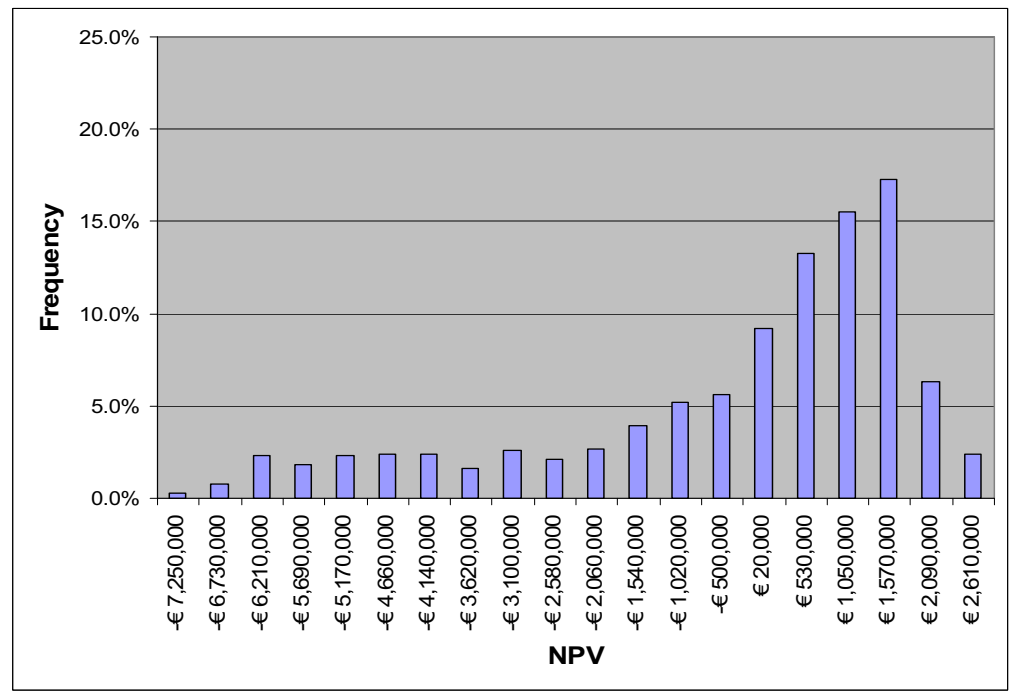

Figure 3. Histogram of the project value

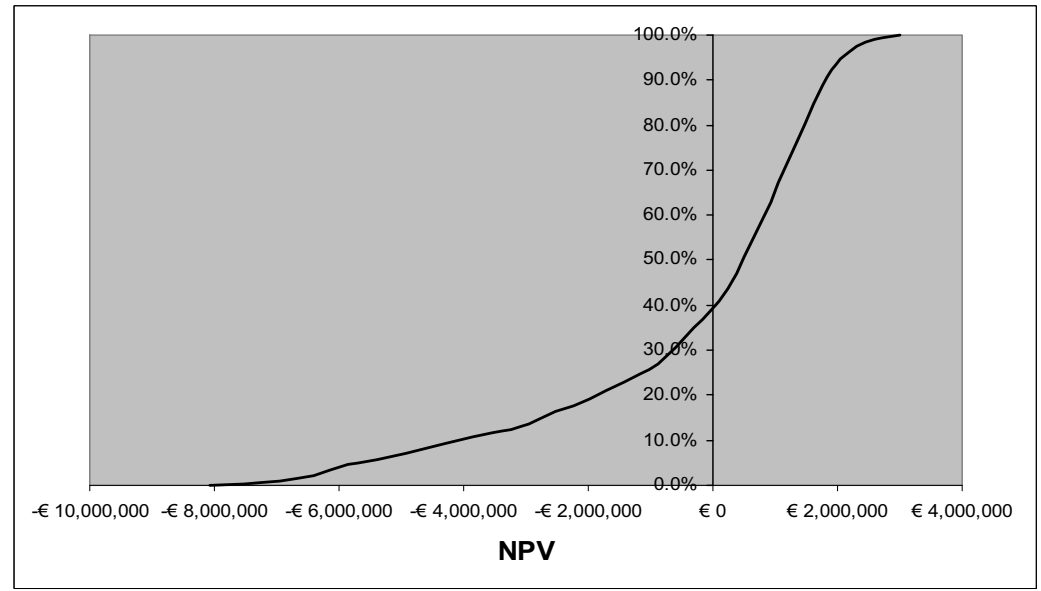

Figure 4. Project VAR chart 
of project uncertainties. When the cash generation model has been formed, it is important to differentiate between those model variables that can be predicted as fixed numbers and random variables that must be predicted as probability distributions. As to the latter, there are two general approaches to define their probability distributions.

The first approach assumes that there are available historic data on a particular variable. In that case, we can apply timeseries analysis, regression analysis or bootstrap analysis. Microsoft Excel significantly eases the application of these methods. ${ }^{2}$ The second approach assumes that there is no any historic track on the observed variable. In that case, it is necessary to rely on benchmarking of other similar companies, and subjective experience and expertise. The analysts often use triangular distributions derived from three crucial projections of relevant stakeholders: optimistic, pessimistic, and expected. ${ }^{3}$ Simulation of project NPVs is quickly done with Excel add-in SIM.xla (Savage, 2003) or software packages such as Crystal Ball or (a)Risk.

\subsection{Incorporation of managerial flexibilities}

MCS result is a probability distribution of project value. Managers strive to shift the probability distribution chart from left to right by exercising the existing or additionally incorporated managerial flexibilities. The applicative model throws in managerial flexibilities through carefully formulated if-then decision rules 4 . For example, managers may abandon the research and development pharma project if costs in preclinical trials exceed the defined budget. Likewise, managers may insist on building additional parking garage floor, if the number of cars surpasses critical threshold.

Definition of adequate decision rules is a very sensitive job, which requires deep diving into the core of the project. If the analysts want to bring valuable flexibilities into the project, to represent them with adequate decision rules, and shift VAR chart to the right, they must utterly understand the project's nature and complex dependencies between project uncertainties and flexibilities. The key aspect of modeling managerial flexibilities is linking project uncertainties and project flexibilities. For example, managers will base their decision on R\&D project abandonment on costs' trends in preclinical phase. Similarly, managers will decide on building additional parking garage floor depending on the car number propensity.

It is very important to differ flexibilities already attached to the project from flexibilities, which are ex post, based on additional investments, incorporated into the project. Large investment projects have a certain number of attached managerial flexibilities. For example, oil exploration projects have built-in abandonment options at each gate of sequential decision-making. Abandonment option value is derived from the fact that the company might avoid large losses by reacting quickly on dissatisfactory profitability indicators. On the other hand, adding new flexibilities in the model costs money. For example, the purchase of new flexible equipment that might use both oil and natural gas introduces an option to use one of two energy sources depending on their current market price.

After defining decision rules, financial

\footnotetext{
2 Forecasting based on time-series analysis may be easily done with Forecast.xla add-in, regression analysis with Data Analysis module, and bootstrapping with statistical function gen_Resample included in SIM.xla add-in., ${ }^{3}$ Triangular distribution can be created in Excel with gen_Triang statistical function included in SIM.xla add-in., ${ }^{4}$ Decision rules are easily created in Excel with regular IF-THEN function.
} 
model gives another probability distribution chart of the project value, which now incorporates the value of managerial flexibilities. The option value is calculated as a difference between average NPV, after the flexibilities are included in the model, and average NPV without the value of flexibilities (i.e. average NPV calculated by MCS tool). It is vastly important to include flexibilities one after another and to monitor their isolated impact on the NPV distribution. This way, it is possible to rank flexibilities according to their contribution to the value of the project. However, the overall value of flexibility is not the simple sum of individual option values. The values of options are non-additive and interdependent. Therefore, they must be valued as an integral system, as a compound option.

If the probability distribution has shifted to the right that means that managerial flexibilities have value in terms of decreasing the risk of large losses, when the left tail shifts to the right, and in terms of increasing probability of gains, where right tail shifts to the right (Figure 5).

The final VAR chart represents the basis for 'go-no go' decision-making. As opposed to numbers, it is not that easy to compare probability distributions. If the manager' priority is to reduce the probability of losing money he/she will focus on the left-hand tail of value-at-risk chart even at the expense of a reduced expected gains. Conversely, if the preoccupation of the manager is to better exploit upside opportunities, the focus is on the right-hand tail of NPV distribution. The final decision is based on manager's subjective risk aversion. It means that two managers may make completely opposite decisions regarding the same VAR chart.

The main advantage of the presented applicative model lies in the fact that the project value is represented by probability distribution, instead of a single number. The next benefit of applicative ROV model is that it does not give ready-made solutions to decision-makers, but only directions and alternatives for making better decisions. While thinking about key uncertainties and flexibilities and different ways of improving risk profile of the project, managers are learning about the project and building their intuition behind numbers.

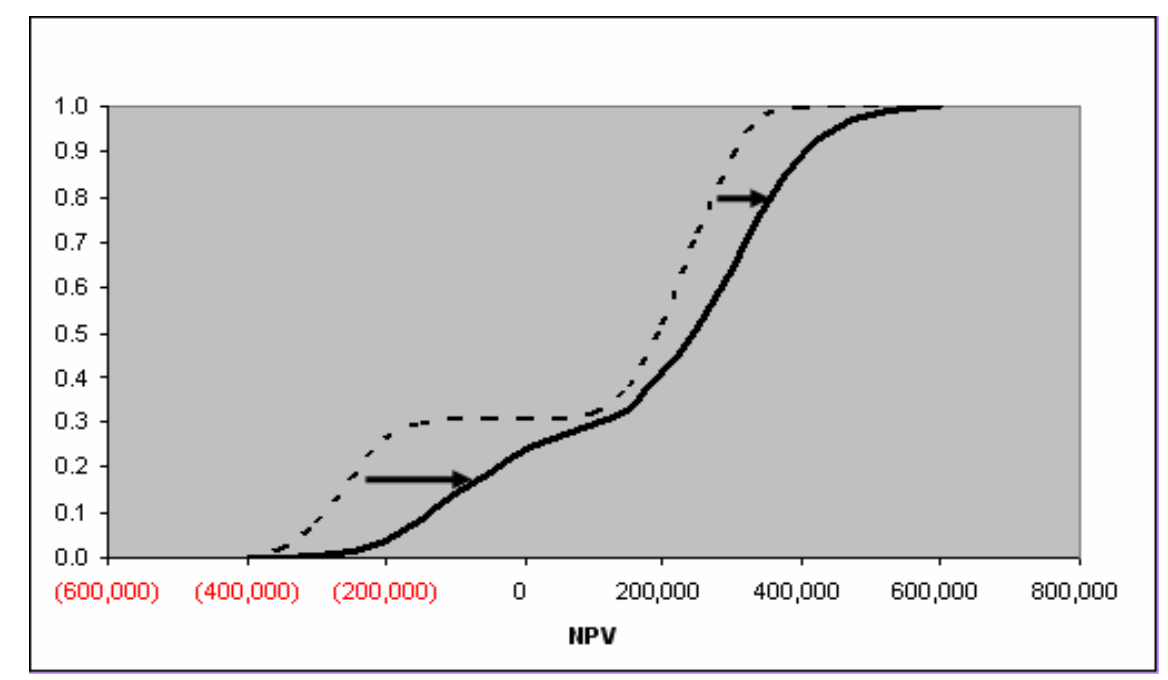

Figure 5. Shifting VAR chart to the right 
The greatest danger of applicationoriented methods is temptation to overcomplicate analysis by introducing too many uncertainties and flexibilities. Model complexity may be controlled by careful introduction of new complexity to the base model. Also, as every project is a new story, thus no universal tools can help. Consequently, applicative procedures might be very time-consuming. Finally, applicative model technically fails to incorporate or properly quantify some variables, such as timing of entry to the next project phase or the behaviour of competitors or partners. For this purpose, it is advisable to use complex dynamic optimization models and game theory models.

\section{ILLUSTRATIVE EXAMPLE}

In the following text we will present a real-life drug development project (within biotech company called Cambridge Antibody Technology - CAT, the project done during 2003 by the author), more precisely on a breast cancer drug designated to patients at the advanced stage of disease. It is assumed that the drug is at the beginning of clinical trials. In other words, the drug has successfully passed all previous hurdles, starting from identifying the target, discovering the appropriate compound and testing in pre-clinical trials. Clinical trials are usually divided into three main phases. Firstly, the potential drug is assigned to healthy volunteers. Secondly, it is exposed to the numerous tests of efficacy. Finally, it is prescribed to the palpable number of patients in order to measure statistical evidence of efficacy. In our project, we roughly divided clinical trials into two basic sub-stages: exploratory and confirmatory. The third stage in a pipeline is regulatory approval and finally, the fourth one is drug launching.

The patent protection starts next year and expires in 15 years. The using of patent costs money: licence fees (symbolic sum of $£ 0.1$ mil. every year during the patent life), royalty payments (6\% from the drug sales) and milestone payments (in this case these are lump sums paid to the patent owner at the beginning of each phase; it is usually a matter of contract agreement between two firms). Besides patent-related costs, the project incurs diligence provision costs, incremental and overhead costs, development costs and, finally if the drug is launched, production and sales costs. On the other hand, the only cash inflows come from sales revenues if the drug is launched.

We are focusing on three key uncertainties: demand, development costs and the most important one, technical uncertainty. Demand is fluctuating 35\% up and down from the forecasted value (subjective judgement of marketing managers). The price is assumed to be fixed at $£ 10,000$ per treatment. Development costs are less uncertain, $20 \%$ up or down (subjective estimation of R\&D managers). The probability of technical failure in each stage is determined according to the historic experience of people from R\&D department. The probability that the drug will pass to confirmatory stage is $30 \%$, to regulatory approval stage $50 \%$, and that the drug will be filed and approved 95\%. It is apparent that the probability of drug (technical) failure decreases as the drug goes ahead through the pipeline. In order to provide more or less reasonable movement of demand and development $\operatorname{costs}^{5}$, we incorporated a sort of random walk in modelling of their fluctuations. This way statistical dependence inside these variables is recognized and assessed. 
The key flexibility in the model is option to abandon the project after exploratory stage, if the development costs exceed 'red line’ (£12.1 million). People from CAT asserted this "ceiling" taking into account cash flow constraints. Therefore, if the project is likely to be too expensive for the firm, it is advisable to abandon at this point before the firm has committed huge investments in confirmatory stage (forecast $£ 100$ mil.). In our model, the value of this flexibility is positive (Figure 6). This is "insurance or robustness nature" of all putlike options (left-hand tail of NPV distribution shifted to right, which means that we insured ourselves against downside scenarios). The option already exists in the project and the exercise of abandonment option in this case does not cost money. The indirect, intuitive cost is the lost of possibility to earn money after the drug is launched.

The second flexibility is to abandon three years after launching if demand is less than critical level $(21,200$ sold treatments). The logic is: we already invested large amounts of money in previous stages (more than $£ 400$ million) but if demand is insufficient we can, at least, save some money (by cancelling further production and sales costs, which are $£ 78$ million a year). At this point of time, option to abandon is not rational, because we have already invested large amount of money on one hand, and have reasonably high demand forecasts for coming years on the other hand. It is advisable to 'keep the option open' and to try to recoup, at least the invested money (terminal value should be also taken into account). Nevertheless, this 'flexibility' is kept in a model in order to show how badly formulated decision rules may destroy value. Therefore, the value of flexibility depends on the level of uncertainties as well as on the ability of managers in using it.

The third option taken into account here is option to sell licence for the drug if it is not regulatory approved. The logic is: the drug is not regulatory approved, but its value at this stage is huge because it has successfully passed all clinical tests. It is probably rejected because it needs some modifications

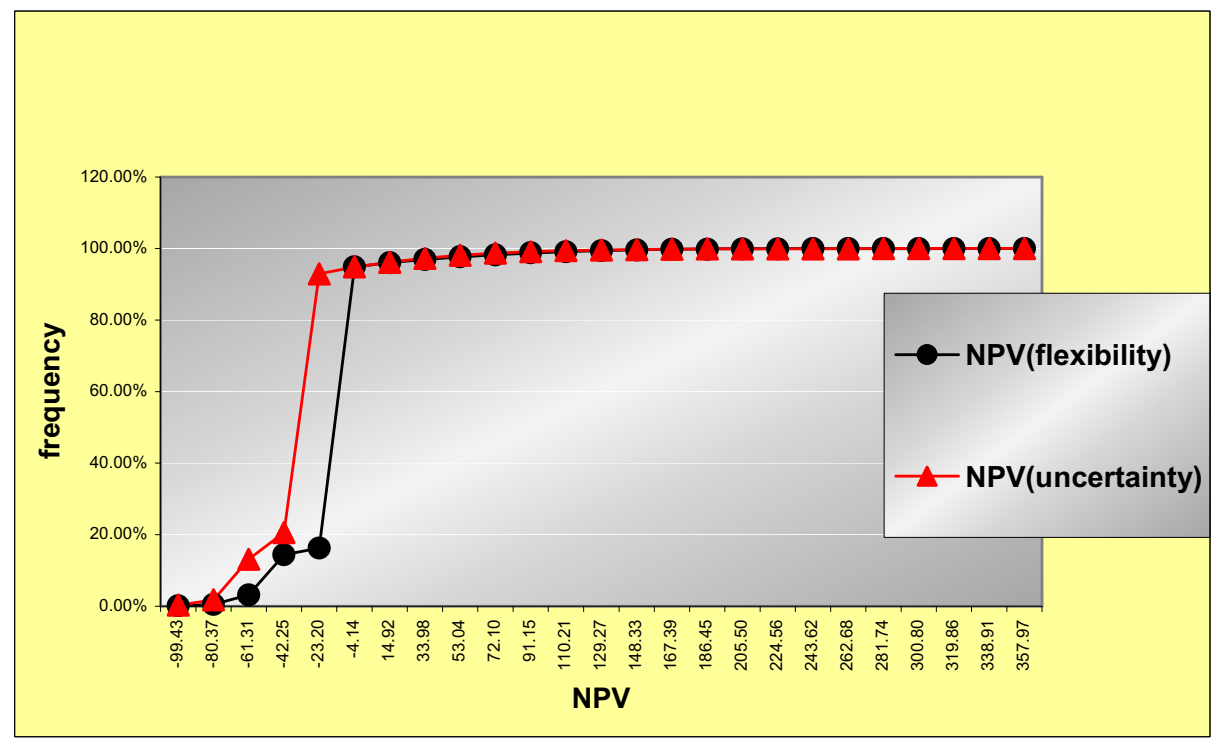

Figure 6. The value of abandonment option after exploratory stage

5 If the demand is high in year $t$, it is more likely that it will take on high value in year $t+1$ as well. We also assumed that high costs in year $t$ cause high costs in year $t+1$. 
of dosage level or additional statistical tests. Regarding this project alone, this option is valuable (Figure 7), because we can recover some previous costs committed in exploratory, confirmatory and regulatory phases (around $£ 130$ million). From the portfolio or top manager point of view, this is not maybe a smart move, because just a little more patience and relatively small additional investments may result in a worthwhile product with alternative indications and formulations. Also, the know-how or sideproducts, acquired in the previous process, might be used as a path for exploring new compounds.

Altogether, we have a compound option, where several real options exist simultaneously. The problem is that values of options are interdependent and non-additive. For instance, abandonment of project in early stages kills all other subsequent options. That is the reason why we must value all the options as a system.

From technical point of view, the starting point of financial model is passive (fixedplan) NPV. It is useful because it gives the logic of cash flow structure and generation, which is an appropriate starting point for the analysis to come. Firstly, for the sake of consistency of spreadsheets, we had to incorporate in this model the probabilities of technical success after exploratory, confirmatory and regulatory stage $(30 \%$, $50 \%, 95 \%$, respectively). Secondly, it is expected that the drug will be sold very well two years after the patent has expired (from 2018 to 2020). After 2020 the sales will steeply decrease by $25 \%$ per year. This is important information for terminal value calculation [cash flow 2020 / (discount rate growth rate in cash after 2020)].

The next step is Monte Carlo simulation, which incorporates uncertainties (demand, development costs and technical uncertainties) in our passive NPV by deriving all their possible values with certain probabilities. Therefore, we have probability distribution of all uncertain inputs instead of "one best guess" for each of them. In this project, we ran 10,000 simulations for NPVs depending on these uncertainties.

Histogram and value-at-risk chart helped

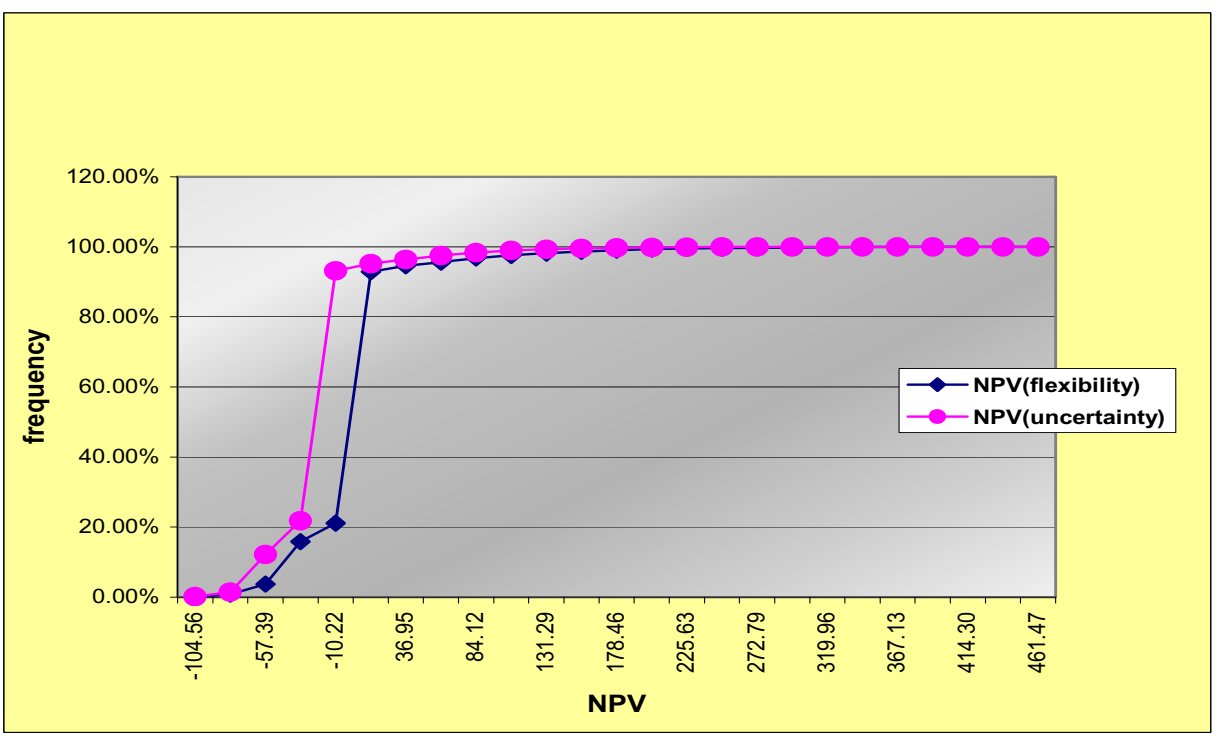

Figure 7. The value of option to license drug 
us to visualise all possible outcomes (NPVs) and their individual or cumulative probabilities of occurring. The probabilities that NPV will take on value in a certain range are given in the Table 1.

The probability of getting negative NPV is around $93 \%$. It is apparent that around 70 per cent of NPVs take value between -10 and 0 , which means that the project mostly failed after exploratory stage. In around 14\% of scenarios NPV is between -50 and -10 million (when project fails to pass confirmatory and enter regulatory phase). Very rare, project fails to be regulatory

Table 1. NPV values and their probabilities

\begin{tabular}{|c|c|}
\hline NPV range (£ mil.) & Probability (approximately) \\
\hline Less than -£100 & $0.1 \%$ \\
\hline$(-50,-10)$ & $14 \%$ \\
\hline$(-10,0)$ & $71 \%$ \\
\hline $0-10$ & $0.9 \%$ \\
\hline $0-50$ & $3.3 \%$ \\
\hline $0-100$ & $5 \%$ \\
\hline $100+$ & $1.9 \%$ \\
\hline
\end{tabular}

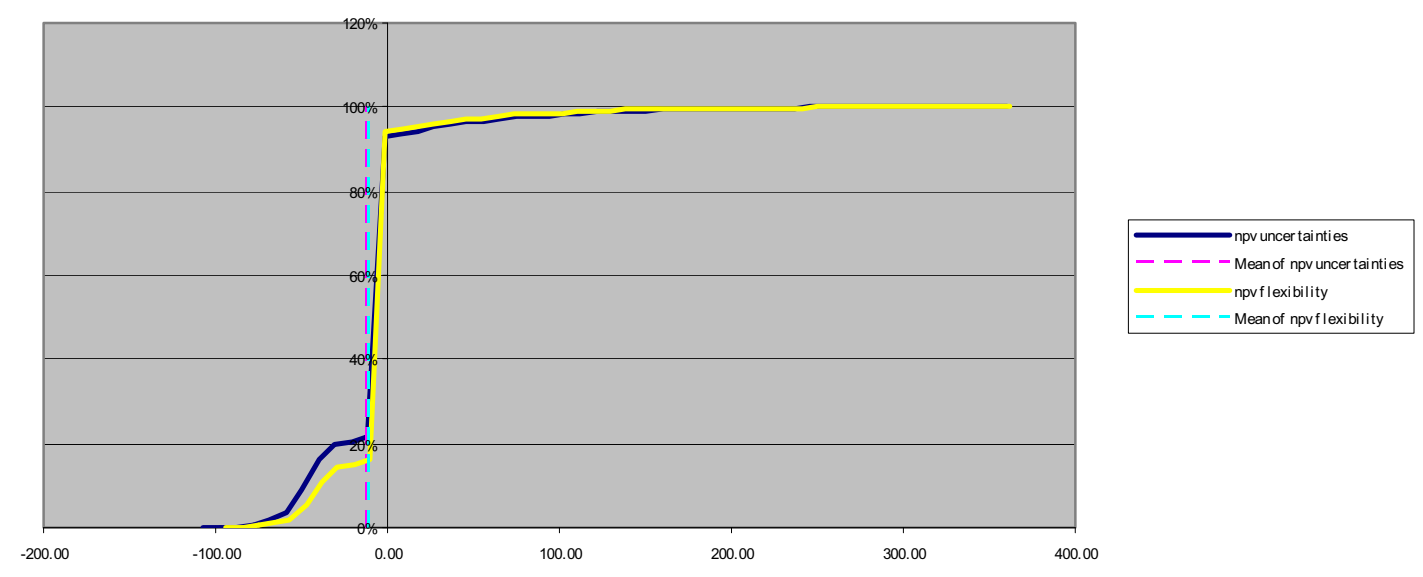

approved. Only in slightly more than $0.1 \%$ of scenarios loss is greater than 100 million and the maximum loss is around $£ 120$ million. On the other hand, the probability of getting positive NPV is around $7 \%$. The probability of positive NPV above $£ 100 \mathrm{M}$ is around $2 \%$. The maximum positive NPV is around $£ 400 \mathrm{M}$, which means that drug does not have blockbuster potency.

The next step is to incorporate decision rules. The aim is to embed only the decision rules (managerial flexibilities) that enhance the value of the project (in our project: abandonment and outlicencing options). That way we got the final VaR chart for the project with incorporated values of managerial flexibilities (Figure 8).

\section{CONCLUSION}

Investment project valuation requires incorporation of the value of managerial flexibility in the project value. More sophisticated tools, such as Real Options Valuation (ROV), can help by valuing these managerial intangibles. The proponents of

Figure 8. Final VaR chart of the project 
ROV argue that the value of managerial flexibility must be identified and incorporated in the value of the project. This way some investment alternatives with negative NPV, but with valuable opportunities, might be pursued.

The proposed solution in the paper is application-oriented valuation model based on a widely-accepted software package Microsoft Excel. The proposed ROV model has three valuation steps. The first step assumes generation of project's projected cash flows and calculation of conventional NPV number. On the passive basis developed in the first step, in the second step, analysts relax static projections of input variables by their replacement with carefully derived probability distributions. All model uncertainties that cannot be predicted with certainty are displayed with probability distributions, based on historic data, experience, and expert intuition. In the third step, managerial flexibilities are introduced into the model through decision rules, which represent contigency plans for the exercise of managerial flexibilities. The idea behind this is to shift probability distribution of the project value to the right by careful selection and optimization of decision rules. After the introduction of managerial flexibilities into the valuation model, managers interpret the final probability distribution of the project value and make final investment decision on the basis of their subjectively observed riskreturn trade-off.

The value of the presented model lies in its step-by-step nature, which secure thorough understanding of the valuation process and results by decision-makers, which boosts their trust in the model's recommendations.

\title{
ПРИМЕЊИВИ МОДЕЛ ЗА ОЦЕНУ ИНВЕСТИЦИОНИХ ПРОЈЕКАТА ЗАСНОВАН НА МЕТОДОЛОГИЈИ РЕАЛНИХ ОПЦИЈА
}

\author{
Драган Лончар*
}

Економски факултет, Универзитет у Београду, Каменичка 6, 11000 Београд

\section{Извод}

Овај рад се бави применом методологије реалних опција при евалуацији инвестиционих пројеката. Основни циљ рада је да презентује примењиви модел евалуације пројеката, који омогућује доносиоцима одлука да спроведу конвенционалну анализу нето садашње вредности, увођењем кључних улазних варијабли по методи случајног избора. У те сврхе, употребљена је Монте Карло симулација, менаџерска флексибилност, као и дефинисање правила узрочник - последица. Насупрот већини метода евалуације које се могу наћи у литератури, модел који је овде представљен прихвата једноставну премису да је вредност пројекта унапред непозната величина. Вредност пројекта није дата само износом нето садашње вредности, већ и преко дистрибуције кумулативне вероватноће.Финална менаџерска одлука не заснива се само на фиксним правилима одлучивања, већ и на њиховом односу према ризицима, односно на једноставном балансу између ризика пројекта и повраћаја инвестиције.

Кључне речи: Инвестициони пројект, евалуација, реална опција 


\section{References}

Andersen, M. (2004). Management of complex projects or: how we create something complex. MBA research thesis, University of Cambridge.

Black, F., \& Scholes, M. (1973). The Pricing of Options and Corporate Liabilities. Journal of Political Economy, May-June 1973: 637-659.

Copeland, T., \& Antikarov, V. (2000). Real Options: Practitioner's Guide. Pitman Publishing, New York.

Dixit, A.K., \& Pindyck, R.S. (1995). The Options Approach to Capital Investment. Harvard Business Review, May/June 95, 73 (3): 129-142.

Djuricin, D., \& Loncar, D. (2010). Management by Projects. Faculty of Economics, Belgrade.

Hertz, D. B. (1964). Risk Analysis in Capital Investment. Harvard Business Review, 42 (1): 95-106.

Lander, D.M., \& Pinches, G.E. (1998). Challenges to the Practical Implementation of Modelling and Valuing Real Options. The Quarterly Review of Economics and Finance, 38: 537-567.

Loncar, D. (2007). Theoretical Models for Real Option Valuation: overview and critical reflection. Economics of Enterprise, December 2007: 283-292.

Savage, S. (2002). The Flaw of Averages. Harvard Business Review, November 2002: 20-21.

Savage, S. (2003). Decision Making with Insight. second edition, South-Western College Publication.

Scholtes, S. (2007). Flexibility: The Secret to Transforming Risks into Opportunities. Business Digest, 174: 5-7. 